\title{
Proposal to Structure Social Studies Course According to Toulmin's Argumentation Model
}

\author{
İrem Namli Altintaş ${ }^{1} \&$ Meltem Çengel Schoville ${ }^{2}$ \\ ${ }^{1}$ Faculty of Education Department of Social Studies, Suleyman Demirel University, Turkey \\ ${ }^{2}$ Faculty of Education Department of Educational Sciences, Aydın Adnan Menderes University, Turkey \\ Correspondence: İrem Namli Altintaş, Department of Social Studies, Süleyman Demirel University. E-mail: \\ iremaltintas@sdu.edu.tr
}

Received: April 16, 2021

Accepted: June 20, $2021 \quad$ Online Published: June 24, 2021

doi:10.5539/jel.v10n4p118

URL: https://doi.org/10.5539/jel.v10n4p118

\begin{abstract}
Argumentation Method, which is based on data, claims, justifications, is used in education when it comes to scientific and controversial issues. The purpose of this research, is to demonstrate how argumentation method can be used in social studies courses and to guide social studies pedagogy. Examples of activities related to how argumentation can be used in social studies courses, and suggestions about the role of teachers in the teaching process are presented throughout the research. The research emphasizes forms of argumentation based on reason, particularly the analysis of cause and effect in the analysis of human actions. Using this socio-scientific framework as the basis for social studies classroom instruction allows for meaningful in-class discussions concerning individual and global problems. In this context, argumentation can be used in teaching Content-Based Critical Thinking. In evaluating the use of the argumentation model in social studies courses, this analysis examines three interrelated variables: goals, educational backgrounds and evaluation models.
\end{abstract}

Keywords: social studies, argumentation, critical thinking, goals, educational background, evaluation

\section{Introduction}

A fundamental aim of social studies courses is the use of thinking skills by students. Although these skills are parallel to cognitive development (MEB, 2018), they also cover skills such as reflective thinking, research, and questioning that encourage students to learn the thinking methods used in social science. A task of the social studies teacher is to teach how sociologists, anthropologists, or historians hypothesize, construct research questions, and collect data about social and historical phenomena (Barr, Barth, \& Shermis, 1978) to the next generation of social scientists. Social science as teaching social studies emphasizes a strategy based on research and investigation, and individuals are asked to think about and discuss the problems they face in society from the perspective of a social scientist so that they can understand and positively transform the society in which they live. Consistent with this goal, social studies courses aim to educate individuals who know and use the concepts and methods of social sciences with the basic knowledge and skills required by the contemporary society (Kaymakc1, 2009).

A central purpose of social studies courses concerns, "ensuring that individuals, who know how to access correct and reliable information ... have critical thinking skills" (MEB, 2018). This goal assures that thinking skills are used during social studies courses. Social studies courses, which aim to educate social scientists, are courses in which students' thinking skills are actively used. In this way, students gain skills of evidence-based research and analysis and the practices of evaluating sources of evidence and decision-making in the presentation of their findings. The general and specific goals of developing student critical thinking skills in social studies courses are further facilitated by and through student engagement with the method of argumentation, particularly when teaching socio-scientific subjects. In examining physical and social phenomena, science relies upon logic to define its questions, research methods and the reporting of its results. This system of thought provides a foundation for students to inquire about and examine controversial issues. increase their motivation. However, when creating small or large discussion groups in the classroom, a teacher should carefully take goals, achievements, educational background, and evaluation dimensions into consideration.

Argumentation method is a technique used in the discussion section of daily classroom activities. Discussion is a 
process, where alternative perspectives are evaluated in order to make a decision on a topic, to understand a phenomenon, to solve a problem by groups or individuals with similar or different positions and perspectives (Aldağ, 2006).

Discussion is an important method that allows students to move away from mere speculation, idle opinion, or the mimicking of another person's opinions. Through the use of argumentation, students develop the skills to critically address a concept, problem, or situation through a regulated process that always requires evidence to support an individual's claims. The argumentation model can be considered as a specific form of discussion method. Toulmin (citation and date?) defines argumentation as a process requiring the use of supported claims, while Yeşildağ-Hasançebi and Günel (2013), identify it as a tool for testing ideas. According to Kaya and Kılıç (2008), data, claims and justification form the basis of argumentation, while promoters, rebuttals and delimiters support validity of the discussion' structure.

Argumentation is simultaneously an individual and social process. From an individual point of view, the process proceeds by creating a reasoned discourse. From the social point of view, the process proceeds by means of discussions among people with opposite views. The use of the argumentation method allows for socio-scientific issues to be discussed in a classroom setting that brings scientific principles and applications into relation with the practices of a democratic society. In this context, a goal of schooling is to develop skills that allow students to reflect the interaction of society and science in their lessons, and that students become critically aware of the social, political, economic and moral challenges that citizens face as members of the society (Sadler \& Fowler, 2006).

There are many studies focusing on relations between argumentation technique, critical thinking and informal reasoning skills in the field of life sciences, especially in the field of socio-scientific topics (Arık \& Akçay, 2018; Boyraz, Hacıŏglu, \& Aygün, 2016; Christenson \& Chang-Rundgren, 2015; Çetinkaya, 2017; Demirel, 2017; Driver, Newton, \& Osborne, 2000; Kaya \& Kılıç, 2008; Simon, Erduran, \& Osborne, 2006).

However, there is limited number of studies that examine the effects of using argumentation for developing critical thinking skills in the teaching socio-scientific topics as a principle pedagogical strategy in social studies courses (Felton \& Kuhn, 2001; Nussbaum, 2011; Torun \& Şahin, 2016; Y1lmaz-Özcan \& Tabak, 2019). This research examines facilitating student critical thinking skills using the argumentation technique in social studies courses, and as a part of the general goals of the educational curriculum.

\subsection{Purpose of the Research}

This research discusses how the model of argumentation facilitates critical thinking, and the elements that need to be considered in this process, that is focused on socio-scientific issues within the context of social studies courses. For this purpose, answers to the following questions were sought:

1) How can an argumentation model be used in the achievements of critical thinking during social studies courses?

2) What are the elements to be considered in terms of educational backgrounds when using an argumentation model during social studies courses?

3) What are the criteria that can be used to evaluate argumentation during social studies courses?

\section{Theoretical Framework}

\subsection{Description of Toulmin's Argumentation Model and Positioning Toulmin's Argumentation in Social Sciences}

Argumentation is defined as: defending claims that are compatible with each other and proven by evidence, all activities to create claims, denial or support of these claims by produced reasons, criticizing produced reasons and confutation of these criticisms (Toulmin, Rieke, \& Janik, 1984, p. 14). Below is a schematic of Toulmin's argumentation and model and relevant terminology: 


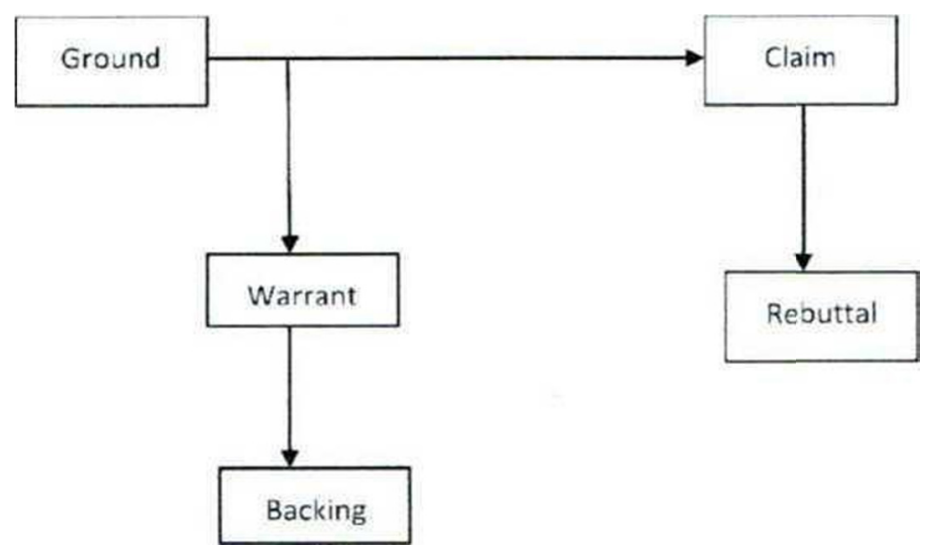

Figure 1. Argumentation model of To11min

Terminology:

- Data: They are facts and grounds used to base and support claims.

- Claims: They are thoughts in which an individual reveals the thing he supports or defends. These thoughts can also be put forward to convince people, who disagree.

- Qualifier: They are elements that indicate the relationship between data and claims.

- Warrant: They are put forward to solidify the claim. In cases where a claim is not accepted, justifications can be included in the process in order to provide support.

- Backing: They are structures that strengthen the connection between key components of the argument and turn it into a convincing form.

- Rebuttal: They are statements showing that claims of those, who disagree, do not contain validity.

This is a design that includes collaborative group discussions to structure and explain arguments, and it is also a process in which questions are asked throughout the dialogue, evidence is collected, claims are explained, and another's claim is evaluated and criticized (Chin \& Osborne, 2010).

The argumentation model has a structure that is student-centered in the teaching of scientific subjects, based on research and questioning, allowing students to examine their own ideas and the ideas of others by creating individual arguments, small group and large group arguments and through the framework of question-claim-evidence. This process also allows students to develop scientific literacy skills (Jang \& Hand, 2016). There are many studies indicating that the argumentation model can be used effectively in science teaching (Arık \& Akçay, 2018; Boyraz, Hacıŏglu, \& Aygün, 2016; Christenson \& Chang-Rundgren, 2015; Çetinkaya, 2017; Demirel, 2017; Driver, Newton, \& Osborne, 2000; Kaya \& Kılıç, 2008; Simon, Erduran, \& Osborne, 2006). In the body of literature, there are also studies on the effects of teaching argumentation model during development of writing skills (Heidari, 2019; Qin, 2013; Qin \& Karabacak, 2010). However, the use of scientific thinking and discussion as a skill employed only in areas such as science or writing limits opportunities for the individual to apply and habituate this skill as a social scientist. Therefore, it is extremely important to integrate the argumentation model into the social sciences (Nussbaum, 2011; Torun \& Şahin, 2016). More frequent inclusion of the argumentation model in the acquisition of higher-level thinking skills can facilitate the process. It is noted that using arguments on social issues can improve students' critical thinking skills and contribute to their creating more effective arguments. Argumentation can be used in teaching many topics such as international conflict, climate change, and migration (Nussbaum, 2002).

Weber states that there is a subjective aspect of the social sciences, and thus social scientists can create controversial topics using this aspect (Trigg, 2005). According to him, if social sciences deal with human actions in a relative or cause-and-effect approach, it is inevitable that more than one opinion shall come into being. There can be discussions on these opinions. In this way, a new thought arises (Özlem, 1993). Weber states that there must be some form of argumentation in social sciences, although he does not specifically use the term. Similar to Weber, Norris and Philips (2003) emphasize that scientific literacy cannot develop without internalizing the structure of arguments; informed decisions only develop when both individual and global problems come into relation with the elements of the scientific method and logic. 
It is important for students to understand and use the concept of primary and secondary claims to differentiate the base opinion of the evidence-based practices employed in the social sciences: a claim can be expressed as an "exchange of opinion between two or more people." A claim can be judged in accord with accuracy or inaccuracy of the antecedents, and validity or invalidity of the reasoning process linking the antecedents. For this reason, it is necessary to closely examine the concept of "opinion" when addressing the concept of claim and to distinguish it from an expression of personal tastes or preferences. In the context of critical thinking, the concept of opinion refers to an individual's expressed judgment in the presence or absence of factual evidence concerning a given topic or subject. In this sense, everyone has an opinion, but not all opinions are of equal value. What distinguishes the value of one opinion over another is the presence of a method, be it scientific, mathematical, or logic, that allows the individual to marshal evidence in support of their claims. When creating opinions in a critical context, investigating the issue, considering alternative views, and deciding which opinion makes sense can be considered as basic steps. Expressing an opinion means presenting evidence while conveying to others what we think about a subject and showing others what we think makes sense. We can talk about many different types of evidence. For example, personal experiences, unpublished reports, published reports, eyewitness testimonies, celebrity testimonies, experiments, statistics, surveys, official observations, and research reviews (Ruggiero, 2017).

Because the social sciences consider phenomena produced by and between human cultures and societies, precise quantitative measurements are difficult to test and verify across populations and different historical conditions. Thus, to make fully supportable claims as a social scientist requires both a knowledge of and commitment to the practices of science, critical thinking, and argumentation. As more moderate empiricists become less-strict about the necessity of testability, it becomes difficult to distinguish between real science and pseudo-science belief systems. For the social scientist, another problem with testability results from the relationship between experience and interpretation. If every experience proposition is also an interpretation, it means that every factual proposition is open to reinterpretation. Seemingly contradictory evidences can be made consistent with an adopted hypothesis by reinterpreting the hypothesis (claim) or the new evidence. The most important problem resulting from this uncertainty and interpretation is the competition between theoretical orientations (Benton \& Craib, 2008).

\subsection{Relationship Between Critical Thinking and Social Studies in Argumentation Model}

There is a close relationship between the ability to use argumentation as a model in discussions and critical thinking skills. There are different opinions about defining critical thinking skills. For example, according to Ennis, critical thinking is a logical reflective thinking process focused on deciding what to believe and what to do (Ennis, 1987). According to Lipman, it is a way of thinking that leads to good judgement, because it is sensitive to the context in which it is located, based on criteria, and has a self-correcting structure (Nosich, 2012). Common points between these thoughts include the ability to analyze your thoughts, to present evidences, to solve problems, to make decisions, and to evaluate the processes of critical thinking. These common points also seem to be linked to Toulmin's argumentation model.

However, similar to the argumentation model, not every opinion is considered an example of critical thinking. Critical thinking occurs only when an individual reflects on his/her thinking (Nosich, 2012). Individuals' interpretation of solutions and ideas directed at them as "the most accurate" can be interpreted as an indication that the individual is not thinking critically. Because this person does not evaluate the current situation by passing it through his/her mind filter, and he/she accepts the information presented to him/her as it is. Cognitive dimensions of critical thinking skill that explain a cognitive skill can be listed as sense-making, analysis, evaluation, inference, explanation, self-regulation (Facione, 1990).

Ming-Lee Wen (1990) classified basic arguments of critical thinking as "inquiry, comprehensive thinking, free thinking, and reconstruction" (Akt. Şenşekerci \& Bilgin, 2008). According to this approach, beside the fact that critical thinking is accompanied by rational thinking, it (critical thinking) also boosts mental thinking skills of the individual.

In a social studies program, critical thinking, which is evaluated during cognitive learning processes, is taught by following an integrative teaching method. Here, it is not about teaching skills directly, it is about integrating these skills within the social studies program. When we look at the literature, we can see that teaching critical thinking in a content-based way and the need for students to learn achievements in question in a consistent and arranged way under guidance of a teacher are emphasized (Doğanay, 2016; Fair, 1967).

Fair (1967) states that effective thinking methods in social studies are important in establishing connections with the real world, allowing primary and secondary school students' thinking skills to increase. He noted that the teacher can also increase students' ability to ask questions by asking effective questions in the lesson, thereby modeling the practices required for critical thinking and argumentation. 


\subsection{Teaching Social Studies}

The 2005 Social Studies Curriculum included basic critical thinking skills as an essential component for 21st century teaching. This new curriculum assists secondary school social studies students to use their mental skills such as critical thinking, decision-making, and group discussion. These skills are achieved by students' active participation in activities, not by memorizing (Yapıc1 \& Demirdelen, 2007). An activity-based social studies curriculum also helps students improve their problem-solving skills (Sönmez, 2010). Social studies students who participate in these activities more readily transfer the knowledge and skills of critical thinking and argumentation.

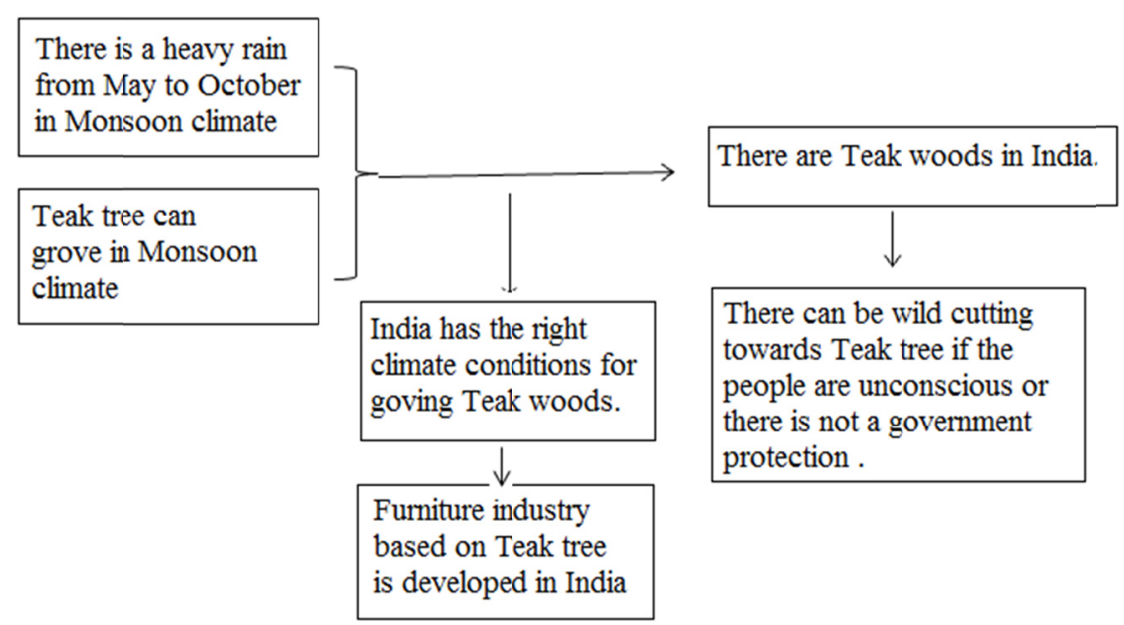

Figure 2. How to use toulmin's model in a social science goal

Above, Figure 2 explains teaching of proposed content-based critical thinking. The discussion method and the argumentation model in the content of the course provide a guiding quality in the teaching of controversial topics in social studies courses. In the course of social studies, there are many different topics in which argumentation model can be used, including discussion that examines the impact of technology on human life, analysis of the positive and negative aspects of globalization, social effects of migration, climate and human relations, discussion on human impact on nature. As can be seen, these are controversial issues that are not pre-judged. In order to increase students' skills, such as researching and thinking during the teaching of these subjects, controversial topics can be put forward and large or small group discussion methods can be performed by taking the argumentation model into account. In addition, attention of the students might be drawn to the course by teachers' asking: "What are the positive aspects of globalization for you?", "What purposes do you use technology for?", or "What might be the goals of people, who have migrated to our country from different countries?" et cetera.

Udall and Daniels (1991) divided Content-Based Critical Thinking into 6 sub-categories:

1) Subject to be taught in the curriculum must be determined.

2) Thinking skills or process to be acquired during the course should be determined.

3) Strategy that the teacher shall follow during the course should be determined.

4) Behaviors expected from the students during the course should be determined.

5) Main thought or generalization to be acquired during the course should be determined.

6) Lesson Plan should be prepared in detail.

Teaching methods and techniques that support active participation are also used in social studies courses. Some of these methods and techniques include, Six Thinking Hats, Brainstorming, Questioning, Intellectual Norms, Developing Vision, Speech Ring, Group Work, Project Work. These discussion activities belong to the argumentation model as discussed in this study (Açıkgöz, 2003; Ayka, 2007; Şenşekerci \& Bilgin, 2008). In science teaching, techniques such as (Naylor, Keogh, \& Downing, 2007; Osborne, Erduran, \& Simon, 2004) argument structuration, predict-observe-explain, phrases table, concept maps derived from students' expressions, competing theories-opinions and evidences, competing theories-cartoons, competing theories-activities are effective pedagogical strategies employed by social studies teachers. 
Toulmin argues that, in implementing the argumentation model, the best practices for the social studies teacher include the development of a structured lesson focused on content-based critical thinking skills. During the use of the argumentation model, it is necessary to also align class plans to the components of the social studies curriculum. There are 4 components: goals, teacher's role, classroom climate, measurement and evaluation.

\subsection{Goals}

Facilitated discussions help students to develop the habits of thinking critically and rationally, while also creating immediate opportunities for students to present their ideas in a safe learning environment (Keskin \& Horzum, 2016). This method, when widely evaluated, is a process in which students transfer their life experiences to a conceptual framework built around the general rules of logic and evidence-based argumentation. During the method, students reveal and discuss their own ideas, values and beliefs. The Social Studies Program supports students in discussing these values and beliefs (MEB, 2018).

Although there are many different discussion techniques within the discussion method, one of the most successful is Toulmin's discussion model, as this model seems to be the most adaptable to subject areas (Alda $\breve{g}, 2006$ ). Toulmin (2009) says that areas related to the topic of discussion in the argumentation model (technology, health, education, et cetera) might change and evolve during the implementation phase of a lesson plan.

In the body of literature, it is pointed out that there is a strict harmony between life sciences scientific process skills and the components of Toulmin's argumentation model. The social sciences, which requires understanding, interpreting and analyzing the data, also presents a favorable environment for the use of argumentation model. Argumentation models in social studies courses can be adapted to other cross-curricular activities during 5th, 6th and 7 th grade classes. In this study examples from 5 th and 6 th grade classes are presented.

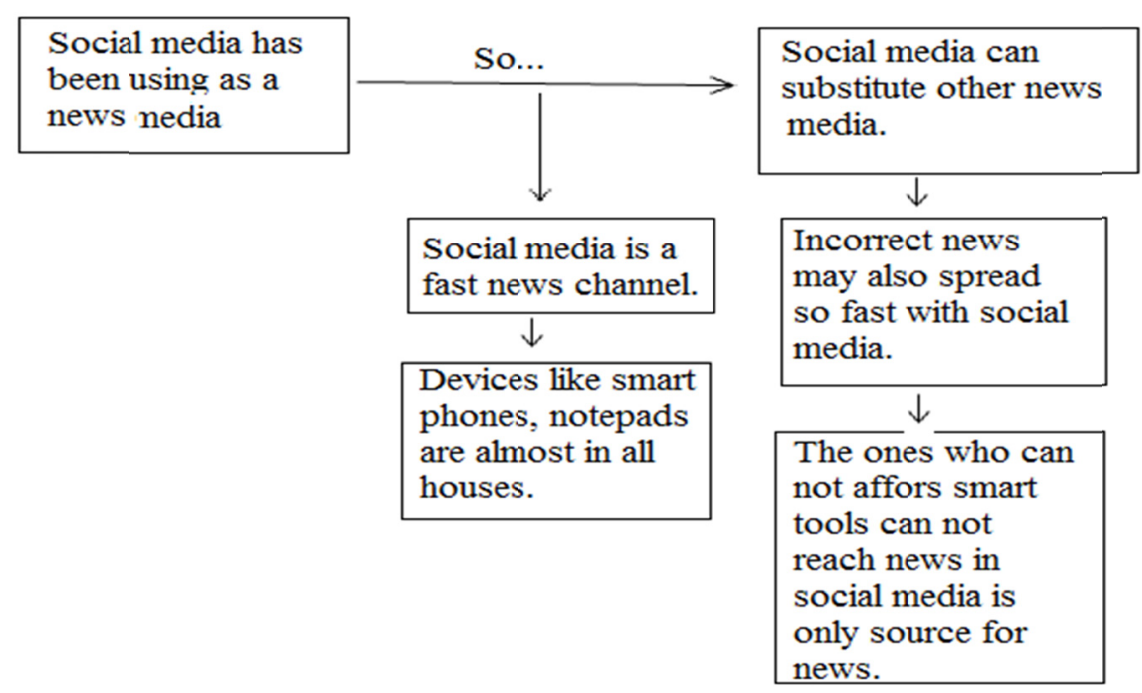

Figure 3. How to use Toulmin's model in a social media related goal

In Figure 3, Person questions the accuracy and reliability of information accessed in the virtual environment (MEB, 2018). An example of how achievements can be examined according to Toulmin's argumentation model is given. But since the ability to use virtual environments (media literacy) is not limited only with 5th Class, this structure can also be applied at other grade levels in the form of increasing the grounds in accordance with the ages of participants.

\subsection{Regulation of Educational Backgrounds}

\subsubsection{Role of the Teacher}

In order for the argumentation model to work, it is necessary for the teacher to facilitate the learning processes of students and strengthen active participation of students by undertaking the role of a guide (McNeill \& Pimentel, 2010). Simon, Erduran and Osborne (2004) state that how a teacher performs guidance in the process of argumentation is one of the important dimensions of argumentation. How a teacher guides and motivates groups during large group and small group discussions is important in terms of process and outcome. Codes and categories of expressions for pre-service and professional development are as follows: 
Table 1. The roles of the teacher during the argumentation process

\begin{tabular}{ll}
\hline Codes & Categories \\
\hline Encouraging Discussions & Speaking and Listening \\
Encouraging Listening & Knowing The Meaning Of Discussion \\
$\begin{array}{l}\text { Defining Discussion } \\
\text { Giving Examples for the Discussion }\end{array}$ & Position Taking \\
Encouraging Opinions & \\
Encouraging Position Taking & \\
Valuing Different Positions & Justification By Evidence \\
Checking Evidences & \\
Providing Evidences & \\
Asking For Justification & \\
Emphasizing Justification & \\
Encouraging Justification More & \\
Playing Devil's Advocate & Structuring the Discussion \\
Using a Template for Writing & \\
Encouraging Evaluation & Evaluating the Discussion \\
Evaluating the Discussion & \\
Process - Using Evidences & \\
Content - Nature Of Evidence & \\
Encouraging for Waiting for a Counter Argument & Creating A Counter-Argument - Debate \\
Encouraging Discussion & \\
Encouraging Reflection & Reflection Concerning The Discussion Process \\
Asking Questions About Mental Changes &
\end{tabular}

Source: Simon, Erduran and Osborne, 2004.

Speaking and listening from the above-listed categories do not include codes for teacher's warning students to listen. However, students' attention to each other's claims and justifications includes checking the data they use when making such claims. Another important point for the functioning of the argumentation model is that it can give students an example of how to make claims or justify claims during discussions and it can be a model for them throughout the entire process (Ford, 2008).

It can be said that even the nature of the questions that teachers ask in the classroom and the responses of students to these questions are elements that determine participation in discussions. In traditional classroom management, the traditional teacher position, in which teachers evaluate how correct answers are after teachers ask questions, is considered an element that negatively affects participation. Neutral responses to open-ended questions and answers asked to students in the process lead to more student participation and support students to reflect more throughout class discussions (Van Zee \& Minstrell, 1997).

\subsubsection{Classroom Climate}

When considering the argumentation model, it is extremely important to consider it in the context of certain dimensions. These dimensions can be explained as the cognitive and conceptual aspects of the argument, epistemic aspect of the argument, and social aspect of the argument. Being focused on problem solving, discussion of alternative explanations, changing explanations and claims, skepticism, justification, inappropriate logical inference and systematic evaluation constitutes cognitive and conceptual aspects of argumentation. Epistemic aspects of argumentation are the use of rhetorical tools, use of evidences, testing of evidences, evaluation of the method and use of scientific expression, while social aspects are; explanation, respect, discussion of opinions, promotion, encouragement, clarification, asking questions and participation (Çetinkaya, 2017). The argument is based on individuals' sharing their thoughts through mutual communication processes. In particular, social aspects of the argumentation point to the climate in the classroom and behaviors of the teacher in order to create and achieve this climate. Positive classroom climate creates an environment filled with respect for the feelings and thoughts between students and the teacher (Miller \& Pedro, 2006), it ensures stronger connection between students and the academic material, ensures stronger participation in the course, ensures production of many more opinions without fear from being criticized (Ghaith, 2010). In particular, in teacher-centered environments where only teachers talk to students and where students are not allowed to talk to each other, argumentation is very unlikely to develop (McNeill \& Pimentel, 2010).

\subsubsection{Measurement-Evaluation}

Since argumentation is a concept that focuses more on processes and justifications than results, it is quite difficult to measure with questions in the style of multiple-choice testing. For this reason, studies that focus on evaluating argumentations attempt to record and evaluate discussion processes, or to evaluate answers to open-ended 
questions in ways in which answers are scored by rating scales.

There are different models that focus on different points related to evaluating the model of argumentation. Toulmin (2009) suggested that in an evaluation model, the argument can be evaluated based on whether or not the argument components he has put forward are used and to what extent they are used. There are evaluation models that focus on different components of the Toulmin model. Some of these can be listed as follows: Naylor, Downing and Keogh Model, Zohar and Namet Model, Erduran, Simon and Osborne Model, Sadler and Fowler Model. Given the fact that there are different types of arguments that focus on analytical, dialectical and rhetorical arguments especially on the basis of the argument, it is also possible to talk about evaluation models that focus on these three different components while evaluating the argument (Çetinkaya, 2017). For example, while some of these models focus on the analytical structure of the argument, structure and robustness of that argument (Osborne et al., 2004; Toulmin, 2009; Zohar \& Nemet, 2000), other assessments focus on students' interactions during argument, in other words the dialectical structure of argument (Naylor et al., 2007), while others focus on the power of persuasion/rhetoric contained in the argument.

One of the models that draws upon Toulmin's components is the model that was put forward by Erduran, Simon and Osborne (2004). Erduran, Simon and Osborne (2004) propose a six-step analytical framework for evaluating the nature of arguments. At the first level, arguments are discussions involving claims and counter-claims. Second-level arguments are arguments that contain data, support, or justifications, but do not contain confutations. Third-level arguments are arguments or counter-arguments that structure data, support, or justifications with weak confutations. Fourth-level arguments are arguments that contain one or more claims with very clear confutations. Fifth-level arguments are comprehensive arguments that involve multiple refutations.

In their experimental study, Zohar and Nemet (2002) recorded discussions of students and collected written preliminary and final test data from students. Discussions and responses to written exams were scored with scores between 0 and 2. As for the justification section, students who did not have any justification were scored with 0 points, students who offered one justification were scored with 1 point, students who offered 2 or more justifications were scored with 2 points. As for the structure of arguments, students without a valid justification were scored with 0 points, while simple arguments containing a result justified with at least one reason were scored with 1 point, and arguments consisting of many parts with more details and examples were scored with 2 points. They also used a 4-Level rating system to evaluate the content of the arguments produced. 1st level was for answers that did not contain any information; 2nd level was for answers, where information was misinterpreted; 3 rd level was for answers with non-original information; 4th level was for answers where original information was interpreted correctly.

Naylor, Downing and Keogh (2007) rated the nature of students' interaction with a seven-step rating system after writing line by line about their argumentation-based interactions in the classroom environment. Ratings were based on the following indicators:

1st Level: Students are not willing or able to engage in any kind of interaction

2nd Level: Students produce a claim that contains information

3rd Level: Students base their claims on something

4th Level: Students put forward more advanced evidence to base their claims on something

5th Level: Students respond to the other group's claims

6th Level: Students can continue their arguments in many different ways

7th Level: Students evaluate the evidences and a decision is reached

According to Sadler and Fowles (2006), in evaluating an argument, a rubric between 0 and 4 points can be used. 0 points - no justification at all; 1 point - there is a justification without foundations; 2 points - there is a justification with simple foundations; 3 points - there is a complex justification; 4 points - there is a complex justification with opposing thoughts.

\section{Conclusion}

In this study, the applicability of Toulmin's argumentation model in social studies courses was discussed. Although studies using Toulmin's argumentation model are mostly found in science-related fields, studies have been conducted in recent years on the results of using the same model in social studies courses. For example, in the fourth grade of primary school, there has been a change in students' attitudes towards social studies and their tendency to think critically through the use of this discussion method and the argumentation model (Yilmaz-Özcan \& Tabak, 2019). Another study conducted on seventh-grade students found that the method of argumentation 
applied in social studies courses had an effect on students' decision-making skills (Torun \& Şahin, 2016). According to a study conducted in the fourth grade of three different primary schools, implementation of the model in social studies courses increased participation in the class, and it was concluded that students improved their questioning and research skills (Yazıcığlu \& Alkan, 2019). Again, in this study, it was stated that the use of the argumentation method shall positively affect the motivation of students in light of the goals set. Similarly, after implementation of an argumentation method in social studies courses in 7th grade, and after completion of an experimental process on implementation of argumentation method in social studies courses, a significant increase in the attitude scores of the experimental group towards social studies course was observed (Aksoy, 2019). Moreover, the use of the argumentation method has shown to increase students' interest in social studies courses and their motivation to work within groups (Aydoğdu-Demir, 2019).

Because the specific content addressed in social studies coursework avails itself to discussions concerning critical contemporary issues and problems, the development of critical thinking and argumentation skills is fundamental. Toulmin's argumentation method best fits in development of above-mentioned skills, suggesting a high probability for the adaption of Toulmin's argumentation method in the field of social studies courses. Careful consideration of the different components of the program must be further studied to assess in relation to the ways in which relevant models may contribute to a healthy functioning classroom environment.

Data, claims, and justifications, constitute the basis of Toulmin's argumentation method and were detected in achievements related to different topics under the roof of social studies courses in 5th, 6th and 7th grades; on the other side, it was observed that there were no limiting or refuting situations. Achievements were mostly focused on justifications that were listed in 18 articles; and, there were 7 achievements containing data. However, it is noticeable that the distribution of achievements involving components of argumentation is balanced between classes. Such a balance shows that the argumentation model can be used when preparing a curriculum for social studies courses (Oğuz \& Demir, 2017).

In order for the argumentation model to work, just being aware of the components of the argumentation and introducing it to students through a topic does not seem to be an effective strategy. Teachers must undertake many different active roles in order for the argument to work in the classroom. However, it is very difficult for students to easily talk about their ideas and produce counter-arguments in the absence of a communication environment based on respect and empathy among students. Because in the argumentation model, the fact that students can easily criticize each other's ideas is one of the important steps.

While evaluating an argumentation, it is difficult to test the effectiveness of the argumentation model with multiple-choice or likert-type measurements. For this reason, in general, studies are conducted through writing down classroom discussions, conducting classroom observations and evaluating students' reports. At this point, it is possible to focus on different dimensions of the discussion so that it can be evaluated. It can be focused on points such as robustness of the argument, nature of inter-student interactions, and persuasiveness of arguments. There are rubrics in the body of literature in order to evaluate different dimensions. Linking socio-scientific issues with the technique of argumentation develops student capacities for understanding others' perspectives and values, enhances student attitudes towards scientific thinking, and contributes to the development of skills and attitudes for critical thinking (Yacoubian \& Khishfe, 2018).

As a result, controversial topics in social studies courses can be structured in accordance with Toulmin's argumentation model. In 5th, 6th and 7th grades, science, technology, society, humans, locations and environments, learning fields are suitable for creating discussion topics. During the use of the model; regulating teachers' behaviors that organize educational backgrounds, creation of a positive classroom climate, and appropriate evaluation of student argumentation allows Toulmin's argumentation model to be implemented more accurately. Furthermore, Toulmin's argumentation model can be implemented in social studies courses if sufficient claims and justifications are established on different subjects. The purpose of all teaching techniques used in this model are to ensure students' active participation and students' achievements of critical thinking skills.

\section{References}

Açıkgöz, K. Ü. (2003). Aktif Öğrenme. İzmir, Eğitim Dünyası Yayınları.

Aldağ, H. (2006). Toulmin tartı̧̧ma modeli. Çukurova Üniversitesi Sosyal Bilimler Enstitüsü Dergisi, 15(1), $13-34$.

Arık, M., \& Akçay, B. (2018). An Effectiveness of Engaging in Argumentation on Students' Ability to Demarcate Science from Pseudoscience. Sakarya University Journal of Education, 8(1), 41-60.

Ayka, N. (2007). İlköğretim sosyal bilgiler dersi eğitim-öğretim programina yönelik öğretmen görüşleri. 
Elektronik Sosyal Bilimler Dergisi, 6(22), 46-73.

Barr, R., Barth, J. L., \& Shermis, S. S. (1978). The Nature of the Social Studies. ETC Publ.

Benton, T., \& Craib, I. (2008). Sosyal bilim felsefesi: Toplumsal düşüncenin felsefi temelleri. Sentez Yayınc1lık.

Boyraz, D. S., Hacığlu, Y., \& Aygün, M. (2016). Argümantasyon ve Kavram Karmaşası Erime ve Çözünme. Gazi Üniversitesi Gazi Eğitim Fakültesi Dergisi, 36(2), 233-267.

Çetinkaya, E. (2017). Bilim sözde-bilim ayrımı bağlamında tasarlanan argümanstasyon temelli etkinliklerin 8. Sınıf öğrencilerinin bilimin doğası görüşlerine, sözde-bilimsel inançlarına ve argümantasyon becerilerine etkisi. Gazi Üniversitesi.

Chin, C., \& Osborne, J. (2010). Supporting argumentation through students' questions: Case studies in science classrooms. The Journal of the Learning Sciences, 19(2), 230-284. https://doi.org/10.1080/10508400903530036

Christenson, N., \& Chang, R. S.-N. (2015). A framework for teachers' assessment of socio-scientific argumentation: An example using the GMO issue. Journal of Biological Education, 49(2), $204-212$. https://doi.org/10.1080/00219266.2014.923486

Demirel, R. (2017). Katı basıncı konusunda argümantasyon etkinliğinin uygulanması. Journal of Inquiry Based Activities, 5(2), 70-90.

Doğanay, A. (2016). Sosyal bilgiler eğitiminde eleştirel düşünme. In D. Dilek (Ed.), Sosyal Bilgiler Ĕ̆itimi (pp. 417-435). Pegem Akademi.

Driver, R., Newton, P., \& Osborne, J. (2000). Establishing the norms of scientific argumentation in classrooms. Science Education, 84(3), https://doi.org/10.1002/(SICI)1098-237X(200005)84:3<287::AID-SCE1>3.0.CO;2-A

Ennis, R. H. (1987). A taxonomy of critical thinking dispositions and abilities. In J. B. B. R. J. Sternberg (Ed.), W H Freeman/Times Books/ Henry Holt \& Co. (pp. 9-26).

Facione, P. (1990). Critical thinking: A statement of expert consensus for purposes of educational assessment and instruction (The Delphi Report).

Fair, J. (1967). Effective thinkinking in the social studies. In J. Fair (Ed.), National Council for the social studies (pp. 167-230).

Felton, M., \& Kuhn, D. (2001). The development of argumentive discourse skill. Discourse Processes, 32(2-3), 135-153. https://doi.org/10.1080/0163853X.2001.9651595

Heidari, F. (2019). The effect of dynamic assessment of Toulmin model through teacher- and collective-scaffolding on argument structure and argumentative writing achievement of Iranian EFL learners. Iranian Journal of Applied Language Studies, 11(2), 115-140.

Jang, J.-Y., \& Hand, B. (2017). Examining the value of a scaffolded critique framework to promote argumentative and explanatory writings within an argument-based inquiry approach. Research in Science Education, 47(6), 1213-1231. https://doi.org/10.1007/s11165-016-9542-x

Kaya, O. N., \& Kılıç, Z. (2008). Etkin bir fen öğretimi için tartışmacı söylev. Ahi Evran Üniversitesi Kırşehir Eğitim Fakültesi Dergisi, 9(3), 89-100.

Kaymakcı, S. (2009). Yeni Sosyal bilgiler programı neler getirdi? Gazi Üniversitesi Gazi Eğitim Fakültesi Dergisi, 29(5), 1530-1545.

Keskin, Y., \& Horzum, B. (2016). Sosyal bilgiler Eğitimi. In D. Dilek (Ed.), Pegem Akademi (pp. 723-744).

MEB. (2018). Sosyal Bilgiler Öğretim Programı. Ankara.

Naylor, S., Keogh, B., \& Downing, B. (2007). Argumentation and primary science. Research in Science Education, 37(1), 17-39. https://doi.org/10.1007/s11165-005-9002-5

Norris, S. P., \& Phillips, L. M. (2003). How literacy in its fundamental sense is central to scientific literacy. Science Education, 87(2), 224-240. https://doi.org/10.1002/sce.10066

Nosich, G. M. (2012). Eleştirel düşünme ve disiplinlerarası eleştirel düşünme rehberi. Anı Yayıncılık.

Nussbaum, E. M. (2002). Scaffolding argumentation in the social studies classroom. The Social Studies, 93(2), 79-83. https://doi.org/10.1080/00377990209599887 
Nussbaum, E. M. (2011). Argumentation, dialogue theory, and probability modeling: Alternative frameworks for argumentation research in education. Educational Psychologist, 46(2), 84-106. https://doi.org/10.1080/00461520.2011.558816

Osborne, J., Erduran, S., \& Simon, S. (2004). Enhancing the quality of argumentation in school science. Journal of Research in Science Teaching, 41(10), 994-1020. https://doi.org/10.1002/tea.20035

Özlem, D. (1933). Felsefe yazıları. Anahtar Kitaplar Yayınevi.

Qin, J. (2012). Applying Toulmin model in teaching L2 argumentative writing. The Journal of Language Learning Teaching, 3(2), 21-29.

Qin, J., \& Karabacak, E. (2010). The analysis of Toulmin elements in Chinese EFL university argumentative writing. System, 38(3), 444-456. https://doi.org/10.1016/j.system.2010.06.012

Ruggiero, V. R. (2017). Eleştirel düşünme için bir rehber. İstanbul. Alfa Yayınları.

Sadler, T. D., \& Fowler, S. R. (2006). A threshold model of content knowledge transfer for socioscientific argumentation. Science Education, 90(6), 986-1004. https://doi.org/10.1002/sce.20165

Şenşekerci, E., \& Bilgin, A. (2008). Eleştirel düşünme ve öğretimi. Uludă̆ Üniversitesi Fen Edebiyat Fakültesi Sosyal Bilimler Dergisi, 14, 15-43.

Simon, S., Erduran, S., \& Osborne, J. (2006). Learning to teach argumentation: Research and development in the science classroom. International Journal of Science Education, 28(2-3), 235-260. https://doi.org/10.1080/09500690500336957

Sönmez, V. (2010). Hayat bilgisi ögretimi ve ögretmen kulavuzu: yeni programa göre düzenlenmiş ders planı örnekleri. Ankara: Anı Yayıncılık.

Torun, F., \& Şahin, S. (2016). Determination of students' argument levels in argumentation-based social studies course. Egitim ve Bilim, 41(186). https://doi.org/10.15390/EB.2016.6322

Toulmin, S. E. (2009). Return to reason. Harvard University Press. https://doi.org/10.2307/j.ctv1m46gf7

Toulmin, S. E., Rieke, R. D., \& Janik, A. (1984). An introduction to reasoning. McMillan.

Trigg, R. (2005). Sosyal bilimleri anlamak. Ankara: Babil Yayınevi.

Udall, A. J., \& Daniels, J. E. (1991). Creating active thinkers: 9 strategies for a thoughtful classroom. Zephyr Press.

Yacoubian, H. A., \& Khishfe, R. (2018). Argumentation, critical thinking, nature of science and socioscientific issues: a dialogue between two researchers. International Journal of Science Education, 40(7), 796-807. https://doi.org/10.1080/09500693.2018.1449986

Yapıc1, M., \& Demirdelen, C. (2007). İlköğretim 4. sınıf sosyal bilgiler öğretim programına ilişkin öğretmen görüşleri. İlköğretim Online, 6(2), 204-212.

Yeşildağ-Hasançebi, F., \& Günel, M. (2013). Effects of Argumentation Based Inquiry approach on disadvantaged students' science achievement. Illkögrretim Online, 12(4), 1056-1073.

Zohar, A., \& Nemet, F. (2000). Fostering students' argumentation skills through bioethical dilemmas in genetics. In Book Fostering students' argumentation skills through bioethical dilemmas in genetics (pp. 181-190).

\section{Copyrights}

Copyright for this article is retained by the author, with first publication rights granted to the journal.

This is an open-access article distributed under the terms and conditions of the Creative Commons Attribution license (http://creativecommons.org/licenses/by/4.0/). 